\title{
Humanity \\ Rearranged: \\ The Polish and \\ Czechoslovak \\ Pavilions at \\ Expo 58
}

David Crowley

Royal College of Art

Expo 58, the Brussels World's Fair in 1958, set exhibitors the challenge of producing a better world in the terms of postwar humanism. In the aftermath of the Second World War and Stalinism, this was identified as an urgent task. Yet some critics from Western Europe viewed the spectacular display techniques—often derived from innovative forms of cinema-as contributing to the alienation of modern life. Spectacle served to screen injustice. This paper explores the ways in which novel exhibition techniques exploited by Czechoslovak and Polish designers in their schemes for Expo 58 can be understood not as distraction but as part of a new political project to produce active citizens in Eastern Europe during the de-Stalinizing Thaw.

In May 1958 Italian critic Bruno Zevi, writing in L'architettura, launched a scathing attack on the Brussels World's Fair. ${ }^{1}$ Describing the mammoth event as an "elephantine trade fair in which every building clamors for the attention of the public with the most crass propaganda," he accused the exhibiting nations of playing on empty national stereotypes. "The English," he wrote of Howard Lobb and John Ratcliff's whimsical British Government Pavilion, "have represented their monarchy with a temple, their industrial production with a glass box and their idiosyncrasies with a pub and a set of caricatures." Those nations that eschewed the past by embracing the world of modern technology were accused of fetishism: "Germany pretends to have forgotten the gas chambers and shows us a distinguished face as if to say that technology justifies everything, whether tanks or electric razors." Whether they fetishized history or technology, all national pavilions in Brussels were outmoded, shaped by what Zevi decried as nineteenth-century thinking. The very premise of a national pavilion was, he argued, redundant. Far from representing progress, the Expo demonstrated what he called the "fear of freedom": the exhibition grounds 
at Brussels—organized in the name of progress—only materialized irrational Cold War anxieties. ${ }^{2}$

Although Zevi was by no means the only critic of the World's Fair, his assessment appeared to strike right at the heart of the lofty aims set for the exposition. Planning the exhibition in the mid-1950s, the General Commission had reflected on the state of the world. Population growth and the rapid pace of technological innovation presented an uncertain future:

The rapid extension of the means of communications; the applications of atomic energy and cybernetics; the use of new means of expression such as cinema, radio, television; developments in science and technique have deeply disturbed the structure of economic and social relations, filling mankind with uneasiness. ... Thanks to science and technique, mankind enjoys increasing freedom from physical effort. But his progress affects only a fraction of humanity: the economically developed countries. A large part of the world is still dedicated to misery. In consequence, there is an increasing contrast between the development of welfare and the increase of poverty. ${ }^{3}$

The solution to these problems was, according to the Expo commission, a "renewed humanism by which man will strengthen his intellectual, spiritual and moral powers" after the disasters of the Second World War. ${ }^{4}$ The organizers put superlative abstractions at the heart of their rhetoric: the exhibition was to demonstrate the renewal of the world ("Bilan du monde pour un monde plus humanisé" ${ }^{\text {) }}$ and of the individual, the "new man" (as contemporaries preferred to gender their subject) of the postwar world.

The World's Fair hardly lived up to its heady slogans. Dominated by the cross fire between the US and Soviet superpowers, the site was also a checkerboard of smaller but nonetheless tense conflicts and repressions: exhibitors were prohibited from explicit commercialism, yet many exhibits in the American pavilionorganized by the United States Information Agency-followed the well-worn strategy of generating envy by stockpiling the glossy products of consumerism. ${ }^{6}$ Inspired by André Malraux's concept of the Musée Imaginaire, ${ }^{7}$ the organizers had hoped in the early stages of their planning to exhibit major modern works of art by artists from all the participating countries to demonstrate that "art does not have political frontiers." ${ }^{8}$ This was to be a singular narrative surveying the "story" of modern art from the beginning of the twentieth century. Yet, the inclusion of Soviet socialist realist canvases, which were "completely foreign" in" style and subject, undermined both the triumphant story of modern art as well as the aim of escaping the gravitational pull of Cold War politics. ${ }^{9}$ The peaceful use of atomic power was a much-repeated theme, with many nations, in their own pavilions and in the International Hall of Science, pressing their achievements in the generation of energy; however, the fair remained largely silent on the military uses of atomic weapons. The rhetoric of human liberation promoted by the Belgian state hardly extended to its imperial possessions in Africa, the Belgian Congo and Rwanda-Burundi, which were represented by replica villages. ${ }^{10}$ The official Expo magazine claimed that Belgium would use the villages to demonstrate its "good work in the vast field of civilising the African 
continent ... industrialising native conditions and furthering social development." ${ }^{11}$ This proved to be a blind prophesy. Leopoldville, as Kinshasa was then known, exploded in riots six months after the World's Fair closed.

Far from being humanism's triumph, Expo 58 seemed like its glittering ruins. It is, perhaps, not surprising that the humanistic rhetoric of the World's Fair was derailed by Cold War divisions, narrow national interests, and the crises and hopes unleashed during decolonialization. Brussels might well be understood as a screen deflecting attention from conflicts and injustice in the world. This was certainly the view of one observer, who, squinting at the French pavilion with its massive wings levered off an enormous counterbalancing shaft, claimed that the shadow of this "immense bird" seemed to stretch as far as Algeria. ${ }^{12}$ The display inside was silent on the effects of the Algerian War, containing no signs of what Jean-Paul Sartre called "life at the moment when the match is put to the fuse." ${ }^{13}$ Similarly, Hungary was represented by a Potemkin structure: the image of a happy world that seemed to have forgotten already the brutal repression of the uprising there eighteen months earlier.

So was the fair's commitment to humanism little more than hollow rhetoric? Were all the participating exhibitors-whether nations, businesses, or individuals-engaged in a common exercise in spectacular dissimulation? The answers to these questions depend much on the perspective from which exhibiting was approached. In this paper, I set out to explore the ways in which the Socialist Republic of Czechoslovakia and the People's Republic of Poland not only responded to the challenge of creating a better future for humanity but also mounted displays that attempted to exorcise cruel ghosts from the recent national past. These were, as I will show, both philosophical and practical questions for architects and designers in the sense that new techniques and modes of display available to them were widely understood as moral instruments that might liberate or deceive their viewers. It is to this matter that we will first turn before entering the exhibition grounds at Heysel.

\section{Humanism and Display}

One reason for the failure of humanism to elevate the exposition resulted, perhaps, from the imprecision of this concept. In the fields of architecture and design, humanism was, it seems, a "universal" worldview, at least in the so-called first and second worlds. In Central and Eastern Europe architects and designers, undergoing sovietization in the late 1940s and early 1950s, were required to espouse socialist humanism, a rhetoric that had been forged in the Soviet Union in the 1930s. Socialist realism, the architectural style imposed on the newly formed Eastern Bloc at the end of the 1940s, marked the arrival of "the era of true humanism" because it promised joy, beauty, and other incontestable rewards to the working classes. ${ }^{14}$ The architectural symbol of the era was the "worker's palace" clad with sentimental murals of peasants, proletarians, and mothers. At the same time, in the West "humanity" and "man" were common platitudes, invoked at almost every important gathering of architects and designers. ${ }^{15}$ The Deutscher Werkbund organized the second Darmstädter Gespräch to 
discuss "Mensch und Raum" in 1951; the Milan Triennale in the same year took "Architettura, misura dell'uomo" as its governing theme; while the following year the Congrès Internationaux d'Architecture Moderne met in Hoddesdon, a town near London, and published its findings there in The Heart of the City: Towards the Humanisation of Urban Life. What was meant by these anthropomorphisms was not always certain. Barry Curtis has described postwar architectural humanism as a "pervasive mood" that "responded to recent experiences of totalitarianism and scientifically planned mass destruction." ${ }^{16}$ Similarly, Ignasi de Solà-Morales has described it "not as a strictly philosophical current but as a cultural climate."17 The impressionistic tenor of words like "mood" and "climate" accurately reflect the widespread but diffused influence of humanism-in its existential and phenomenological modes-in Western Europe in the postwar years.

The view that design should improve the material conditions of human existence was, of course, nothing new; what had changed in the postwar years, in Western Europe at least, was the sense that it could address Existenzfragen (questions of existence). Postwar modernism could not only create the future but also heal the wounds of the recent past. Moreover, that past itself now encompassed the high modernism of the 1920s. Narrow rationalism and Maschinenrausch (machine-intoxication) were seen as a problem, particularly (but not exclusively) by the younger generations of architects and designers. Although rarely making explicit reference to philosophy, architectural debate in the second half of the 1950 s was nevertheless rooted in existential ground. The humanist face of existentialism was clear when it was deployed in postwar discussions of "universal" concerns like existence, shelter, or the creation of "place," a term shot through with phenomenological significance. An emphasis on dwelling or living in freedom was at odds with the spectacular and coercive effects of Expo 58. The exhibition grounds at Heysel were, after all, a dense world of fleeting images and sensations to which the visitor was drawn in the promise of amusement and enlightenment. Exhibitors turned to new media technologies-panoramic cinema, magnetic tape-recording and color television-to excite the weary visitor. Almost every national pavilion, for instance, included a cinema: some took the form of immersive environments, and others were reliant on spectacular effects that would agitate the body. The most widely reported was Circarama, a circular theater built by the Walt Disney Company for the US pavilion. A 360-degree panoramic film, entitled "The USA in Circarama," was projected on its curved walls. ${ }^{18}$ Democracy, like cartoons, looked best in technicolor. ${ }^{19}$ This screen had a Cold War double in the form of the Soviet Kinopanorama, a six-projector, threescreen cinema. The Soviets showed an epic film surveying the life and landscape of the republics, predictably entitled How Broad is My Country. ${ }^{20}$ Inadvertently, the promotional narratives and enveloping technologies rendered the Soviet and American films strangely similar. This symmetry and, in fact, the relentless pursuit of animation throughout the site had, in the view of one American commentator, the negative effect of driving "the viewer even farther into his shell of passivity." ${ }^{21}$ Richard P. Lohse, a prominent Swiss artist and design critic, argued in his review of Expo 58 that the problem of such events was not just a product of their "exaggerated proportions," but that the very techniques employed by the exhibitors produced confusion. "[The visitor] is bombarded with visual effects, distracted by the moving of objects, endlessly rotating and propelling 
each other along, and deafened by ceaseless synthetic noises." ${ }^{22}$ All this constituted, in his words, an "orgy of modernism."

Other modern architects took a different, more positive view of the power of modern communication technology to restore the human. Gestalt theory (and occasionally Maurice Merleau-Ponty's phenomenology) supplied architects with new ideas about the effects of their work on the body. At Brussels, the Philips Pavilion was the product of Le Corbusier's collaboration with composer Edgard Varèse and architect Iannis Xenakis, then an assistant to the Swiss architect in his Paris studio. ${ }^{23}$ Ostensibly a vehicle to demonstrate the talents of Philips's electronic engineers, the Poème Électronique, as Le Corbusier called it, combined film, colored lighting, and music delivered by polyphonic speakers in a darkened, alienating space (fig. 1). The imagery-short filmic clips-was a catalogue of Cold War fears and hopes: mushroom clouds and newborn babies; Godzilla and primitive masks; as well as military technology and primates. The film was carefully choreographed with Varèse's music to produce moments of sensory dissonance. The angular interior of the pavilion sometimes functioned as a baffle, dampening the sound and at other points amplifying resonance like a sounding board. In this way, the "espace acoustique" could be felt by the

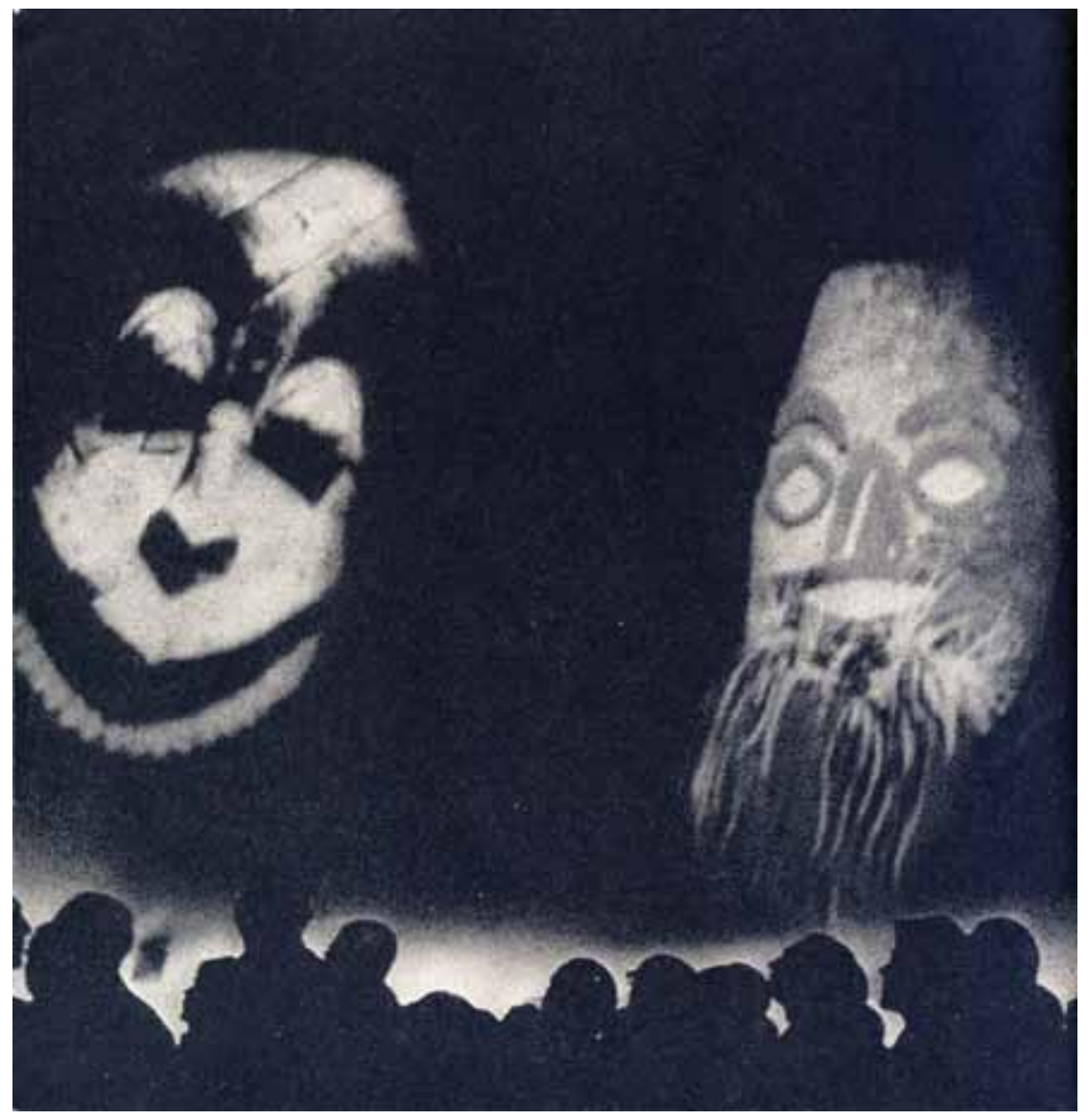

Fig. 1

Viewers watching Sequence 2, "Of Clay and of the Spirit," of the Poème Électronique in the Philips Pavilion, Brussels, 1958, designed by Le Corbusier and Iannis Xenakis (architects) with music by Edgard Varèse. Source: Le Corbusier, Le Poème Electronique (Paris, 1958) 
visitor. The synaesthetic treatment of "son, lumière, couleur, rythme" produced, according to Le Corbusier, "sensations psycho-physiologiques." ${ }^{24}$ This was an example of what Le Corbusier's studio chief and close colleague, André Wogenscky, called "active architecture." ${ }^{25}$ His term signaled an interest in embodied experience. This was more than just a matter of designing practical spaces: the ambitious architect of the late 1950s should conceive his or her field as the design of environments and his object as a new kind of consciousness. The sensory immersion of the body in the world seemed to promise the restoration of the sensing subject: the human could be reimagined as whole, even in the face of the fragmentary and alienating effects of modernity.

Writing at the same time, Roland Barthes asserted the power of the mind in contemporary discussions of the active viewer. Under the influence of Sartre's existentialism and Bertolt Brecht's epic theatre, he argued for what he called "progressive humanism" to contest the sentimental notion of human equality. This was exercised in his famous critique of La Grande Famille des Homames, the MoMA-backed exhibition of photographs on display at the Museé 슬nale d'Art Moderne in Paris in 1956. Black-and-white photographic images of everyday events and themes, like birth, childhood, and work, from across the globe were arranged by Edward Steichen to demonstrate the universal contours of human experience (and have been widely interpreted in terms of Western interests in the individual in the Cold $\mathrm{War}^{26}$ ). According to Barthes, domination and inequality were masked by bourgeois idealism in this muchcelebrated exhibition:

Everything here, the content and the appeal of the pictures, the discourse which justifies them, aims to suppress the determining weight of History: we are held back at the surface of an identity, prevented by sentimentality from penetrating into this ulterior zone of human behaviour where historical alienation introduces some "differences" which we shall here quite simply call "injustices." 27

Barthes objected to the deceptive naturalism that pervaded such images and the techniques of display: "For these true facts to gain access to a true language, they must be inserted into a category of knowledge which means postulating that one can transform them, and precisely subject their naturalness to our human criticism. For however universal, they are signs of an historical writing." What was required, according to Barthes, was the dialectical arrangement of images, statistics, and projections. Only then might an exhibition have the power to stimulate a critical "progressive humanism" on the part of the viewer.

In his insistence on a dialectic of estrangement and engagement, Barthes took a Brechtian perspective on exhibition design. ${ }^{28}$ Brecht himself described how his experimental theater led "to an almost complete destruction of plot and the image of man," that is, the sum of techniques which produce an emotional identification or empathy with the character on stage..$^{29}$ In this moment-according to Barthes- "man" could come to recognize himself as a force of history. The French writer asserted in 1957, "Brecht does not make History into an object, of a tyrannical kind, but a condition necessary for thought. Basing his theatre on 
history . . . is above all to refuse all essence to man, to deny all reality to human nature other than historical reality, to believe that there is no eternal evil, only curable wrongs; in brief, it means to put the destiny of man back in the hands of man himself." ${ }^{30}$ In his insistence on disordering effects, Brecht's techniques opposed the promise of a unified subject. Of all the displays in Expo 58, only one, mounted by representatives of the Socialist Republic of Czechoslovakia, came close to this conception.

\section{The Magic Lantern}

Designed by architect Jindřich Santar and filled with the most sparkling products that Czechoslovak art and industry could provide, the national display represented a response to Nikita Khrushchev's call for "peaceful competition" with the capitalist West (fig. 2) ${ }^{31}$ It was a striking demonstration of the power of modern design in almost every respect. The pavilion was a celebration of "new" materials and architectural technologies like the glass curtain-wall and prefabrication. The accompanying café was a glass-walled box "floating" on narrow columns, like an illustration of the power of modern design to overcome the hold of convention and tradition on the imagination. A suite of buildings organized informally on the site, the Czechoslovak pavilion marked a change of course after a decade of separation from the West (one of the chief authors of a number of schemes in the pavilion recalled the uncertainty that he and his colleagues felt in stepping onto this international stage after the years of isolation ${ }^{32}$ ). The ways in which modern design was used to promote both sides in the Cold War competition has been much researched recently. ${ }^{33}$ It is not, however, the sparkling architecture of the Czechoslovak pavilion or its modern products that demand attention here but the experimental cinema within. ${ }^{34}$

In 1957 Alfréd Radok, a theater director and filmmaker, was invited to develop ideas for experimental performances at Brussels. He had enjoyed a checkered career in the 1940s and 1950s, when judged by official standards, achieving

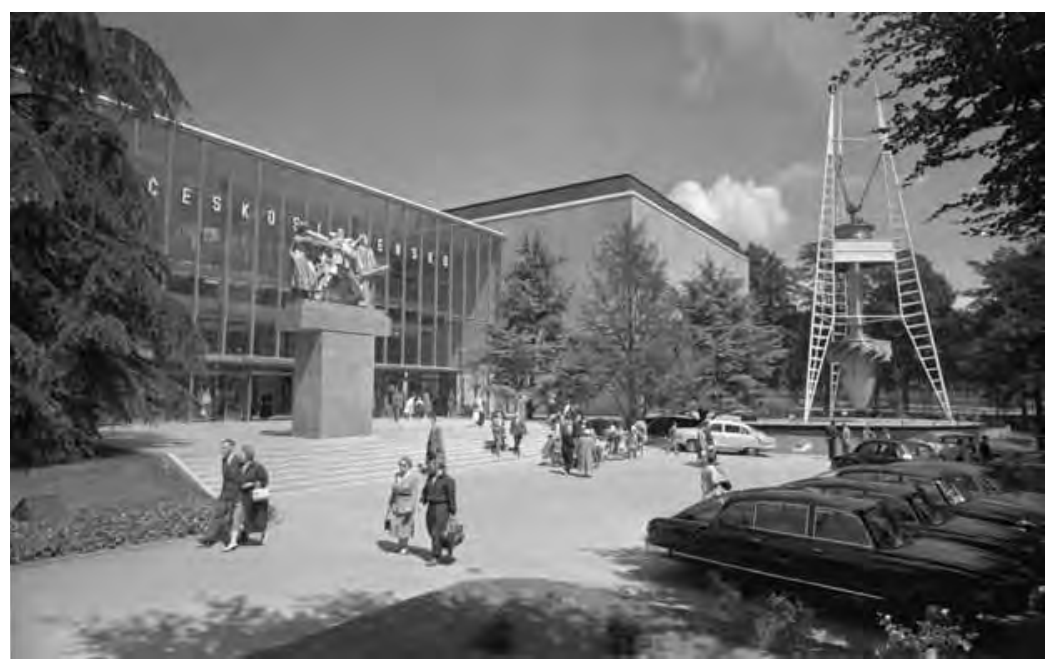

Fig. 2

Entrance to the

Czechoslovak pavilion, designed by Jindřich Santar, at Expo, Brussels, 1958. Source: CTK Fotobanka 


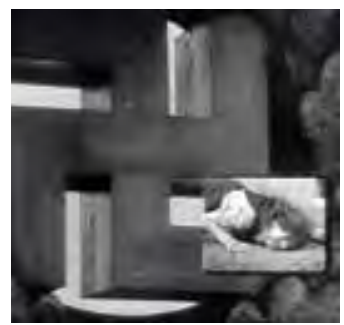

Fig. 3

Still from Distant Journey

(Daleká cesta; 1948-

1949), directed by Alfréd

Radok. Courtesy of the

Národní Filmový Archiv,

Czech Republic.

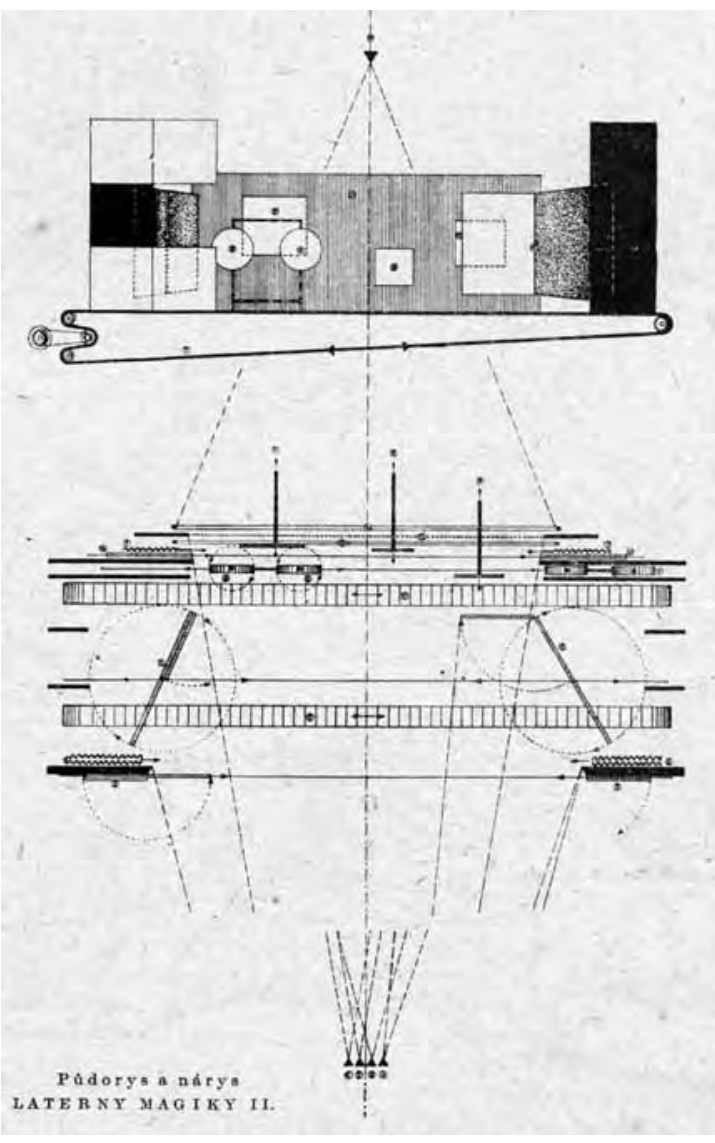

Josef Svoboda, plan and elevation of the stage with moving screens for Laterna

Magika performances in

the Czechoslovak pavilion at Expo 58, Brussels.

Source: Josef Svoboda, exhibition catalogue issued

by the National Theatre, Prague 1961.

success abroad and censure at home for his film Distant Journey (Daleká cesta; 1948-1949).$^{35}$ According to the Stalinist ideologues who policed culture at the time, Radok's film failed to take a sufficiently ideological view of its theme, the Holocaust, or a suitably realist mode. His film combines documentary footage-including Nazi newsreels and sequences from Leni Riefenstahl's Triumph des Willens (Triumph of the Will; 1935) -with expressionist dramatic sequences that tip into nightmare. Terezín, the Nazi ghetto-town, appears as a hideous and incoherent space, filled with obstacles and strangely angled walls and with mysterious off-screen sounds. In Distant Journey dramatic scenes filmed with actors do not cohere with documentary footage to form a synthetic narrative: Radok employed a filmic technique where the dramatic scenes shrank across the screen, forming a frame within a frame (fig. 3). In this technique, the image was always just that: an image. Distant Journey was a great international success when it was screened around the world in 1951; at home it was banned, and Radok's career was put on hold. ${ }^{36}$

Radok's Brussels invitation a few years later reflected a recognition on the part of the Czechoslovak authorities that the aesthetic strategies of socialist realism were uncompetitive on the international stage. With his team of filmmaker 
Miloš Forman and designer Josef Svoboda, Radok was extended a remarkable degree of artistic freedom to plan an elaborate combination theater/cinema in the Czechoslovak pavilion. Only one condition was set: that he use official documentary films about, in his words, "factory work, chicken hatcheries and the beauties of the Slovak holiday resorts." ${ }^{37}$ The resulting Laterna Magika performances--a montage of short tableaux advertising Czechoslovak culture and society--combined ballet, theater, live music, and film. Set designer Svoboda designed an elaborate system of rectilinear and circular screens that could turn 180 degrees to disappear from view or slide silently in and out of place (fig. 4). Three film projectors and one slide projector cast images onto these screens. Some episodes in the performance were based on the formal interplay of contrasting elements: three ballerinas from the National Theatre, for instance, performed a series of spinning and turning movements to the music of Anton Dvo ák before a back-projection of a documentary film of machinery in cotton factories and steel mills. Dancers and machinery both appeared as turning cogs. Later, the same dancers seemed to be joined by others on screen. This was an unsettling disordering of figure and ground, but Svoboda argued strongly that each performance was not a synthesis of cinema and theater:

We would articulate the relations between actions on a screen and on the stage as neither mechanical nor illusionary, neither illustrational filmed projections (à la Piscator) nor naturalistic illustration of reality. Film would remain film and the stage the stage; we would simply exploit the manner in which we joined the actions on stage with those on the screen. ${ }^{38}$

Nevertheless the two modes of expression were to interact. Much celebrated, for instance, was the apparent dialogue between live performers and prerecorded film in the performances. Careful synchronization of the film, sound, and dramatic elements presented the viewer with the surreal and uncanny sense that both the performance and the film were brilliant improvisations. The Laterna Magika promised the supernatural dream of bringing cinema back to life. Radok and Svoboda heightened the strangeness of the theatrical space with careful illusions: the stage was covered with black felt so as to seem indeterminate. Moreover, the projection screens became, according to one contemporary, visible and yet uncertain at the same time: "The projection screen, which until now had been a kind of nonentity, an indifferent window onto nature, all of a sudden is made strange and aestheticized ... ; the composition of several surfaces and in some cases movement becomes part of the spectacle." ${ }^{39}$ The actors were subjected to a remarkable discipline, which regulated their every movement. But in this fantastic world, mechanical animation of people and things produced what one reviewer described as "enchantment": "The dancer catches an image of a dancing star in a giant tambourine held in her hand. A flick of the hands and the image bounces back to ... its place on the screen" ${ }^{\prime 0}$ (fig. 5).

Fantasy in these performances was not meant to signal escape. Central to Laterna Magika's dramaturgy was the principle of repetition. The duplication of the individual-a hostess speaking to her filmic double on screen or the reappearance of individuals and groups in radically different contexts provided by film—was shaped by Radok's ideas about dualism and the responsibilities 


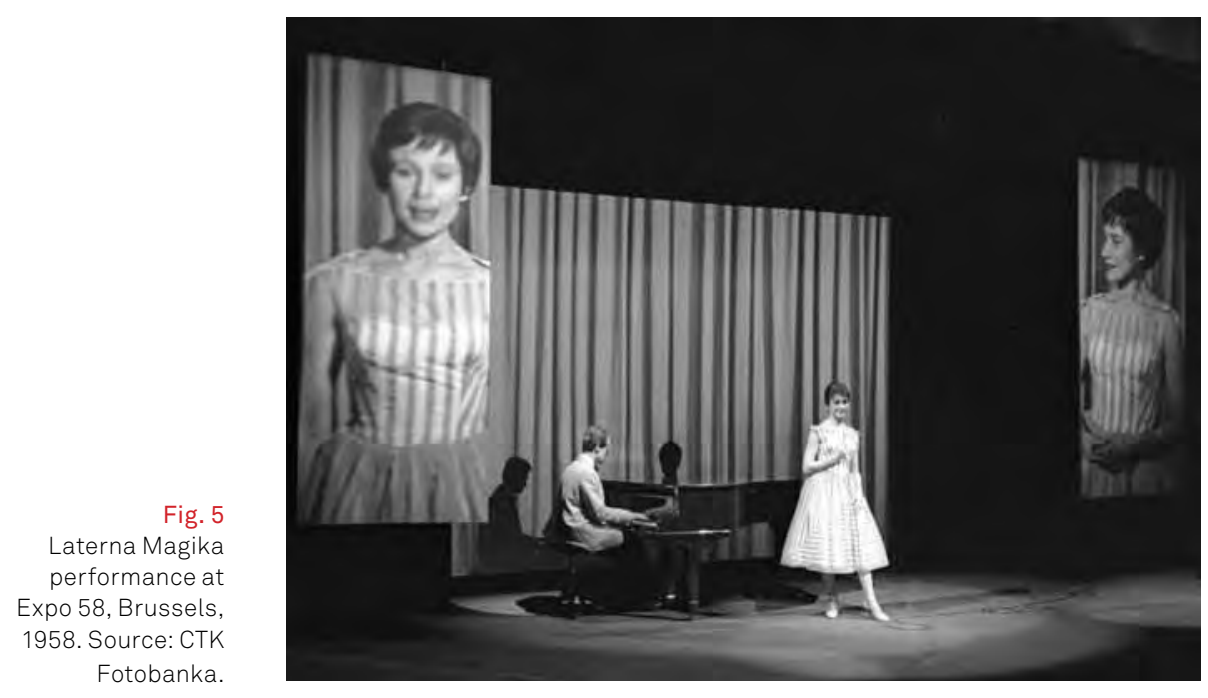

of the individual. Recalling his experiences of the Second World War, Radok expressed a fundamental suspicion of the image:

The name "Hitler" evokes a picture in my mind: A little girl, all sugar and spice, is handing Hitler a bunch of wildflowers. Hitler bends over her and smiles a benevolent smile. To me this image is linked to an awareness of what National Socialism meant, just because the image conceals something. I cannot imagine how it would be possible to describe the war, Hitler, National Socialism, and concentration camps, without this image. ${ }^{41}$

In this photogenic scene, Radok detected a principle of all images (including, as he made clear, those produced by the press in the Socialist Republic of Czechoslovakia) that he described as večnost: "to see in each phenomenon the tension of at least two opposite poles. ${ }^{42}$ Anticipating the interrogation of language offered by the advocates of deconstruction in the 1970s, he asked, how does representation inhabit reality? And how, in particular, is violence repressed in images of peace? or injustice contained in the visual tropes of equality? In selecting the term večnost (which might be translated with the German term Sachlichkeit), Radok also stressed the importance of seeing things and actions without sentiment. ${ }^{43}$ Svoboda-the Laterna Magika designer-described the radical aims of the performance in closely related terms: "The essence of film's artificial reality was also found to lie in the perception of simple signs and in the viewers' need to become accustomed to their patterning and significance and to learn how to look more deeply. The very style of the film seemingly enveloped the characters of the film with its own further significance." ${ }^{44}$ In staking a claim on the engaged viewer, Svoboda also revealed a debt to Brecht's epic theater and its central concept of the Verfremdungseffekt.

In casting the human figure as a mechanical element, the filmic background was to rear into sight. Yet this "background" might feature the same figure. The difference between individual and environment was confounded in a way that 
was later described by Gilles Deleuze: "The rising ground is no longer below, it acquires an autonomous existence; the form reflected in this is no longer a form but an abstract line acting directly on the soul. When the ground rises to the surface, the human face decomposes in this mirror in which both determinations and the indeterminate combine into a single determination which 'makes' the difference. ${ }^{\prime 45}$ Meaning was not produced in the Laterna Magika cinetheatrical montages by any kind of dialectical principle of oppositions: it arose from the indeterminacy of images and things. The figure was not placed at the center of the performance but slipped back and forth, sometimes occupying the foreground, sometimes disappearing. Reified in this way, the human was denied essence or autonomous being. Beneath the sentimental imagery of ballet dancers, musicians, and landscapes, a darker effect was suggested. Emerging from a sovietized environment, which took as its fundamental aim the eradication of alienation from all aspects of life-itself claimed by Stalin as the basis of soviet humanism ${ }^{46}$ - this was a remarkable aesthetic.

\section{Polish Plans}

In Czechoslovakia, as in other parts of Eastern Europe, planning for the Brussels expo was conducted against a background of considerable uncertainty. Khrushchev's "Secret Speech" of February 1956, in which the First Secretary of the CPSU (Communist Party of the Soviet Union) revealed his predecessor's crimes, sent a shock wave across the bloc. While hard-line Stalinists held their nerve in Czechoslovakia, the Hungarians launched an anti-Soviet uprising, and in Poland a wave of criticism directed at Moscow and its local agents rocked the country. Anti-Soviet protests renewed the motivating force of existential humanism in the second half of the 1950s. Once reviled by party intellectuals as nihilism and irrationalism (most famously by Georg Lukács in Existentialisme ou marxisme? [1948], written to demonstrate his loyalty to the Zhdanovschina, or anti-Western Soviet cultural doctrine during the early years of the Cold War ${ }^{47}$ ), existentialist thought in 1956 fanned rousing hopes for individual freedom. Sartre's conclusion to his 1946 essay "Existentialism Is a Humanism" ("L'existentialisme est un humanisme") could be taken as a rallying call: "We remind man that there is no legislator but himself; that he himself, thus abandoned, must decide for himself; also because we show that it is not by turning back upon himself, but always by seeking, beyond himself, an aim which is one of liberation ... that man can realize himself as truly human." ${ }^{48}$ In the streets, universities, and factories of Warsaw and Budapest in 1956 (and later Havana, Algiers, and Leopoldville) men and women were making history.

The communist authorities in Poland struggled throughout 1956 and 1957 to restrain anticommunist sentiment and maintain their "leading" role. Seeking to reduce the ideological temperature, they extended to writers, filmmakers, artists, and architects a greater freedom of expression, and the country became a hot spot of cultural experimentation. The Polish intelligentsia developed a pulsing critique of the alienating effects of Stalinist order during the Thaw, drawing inspiration from the drama that they were not observers of but actors in. With freedom of thought and expression high on their list of demands, they tested 
the tolerance of the post-Stalinist regime: the plays of Ionescu, Sartre, and Beckett were all performed on Warsaw stages during 1957, and experimental music and modern jazz became important features of Polish cultural life. Central Committee member Jerzy Morawski, writing in Trybuna Ludu, acknowledged that Polish intellectual life needed exposure to forms of experimentation, "the normal requirements of artistic development. ${ }^{\prime \prime 9}$ Such pronouncements did not, however, guarantee freedom of speech. When the authority of the Polish communists, Polska Zjednoczona Partia Robotnicza (Polish United Workers' Party), was directly challenged, the state was quick to act. For instance, a major vehicle of critical and anti-Stalinist opinion, the weekly intelligentsia paper Po Prostu, was closed down in September 1957. ${ }^{50}$

Despite a marked antagonism to Moscow, much of the most ardent criticism vented during these years was often from a broadly Marxist perspective, albeit often drawing much from the "young" Karl Marx, stressing the effects of alienation on the individual. ${ }^{51}$ Suppressed in the Soviet Union until "the Thaw," a Marxist critique of Stalinism was licensed by the rediscovery of Marx's early writings like the Economic and Philosophical Manuscripts of 1844. Leszek Kołakowski was, perhaps, the most important of these critics. Regarded as an orthodox Marxist he had been sent by the communist authorities to Moscow in 1950, a journey that those who were ordained to rule Poland were expected to take. The effect of this pilgrimage was different from that intended, revealing to the young philosopher the material and intellectual poverty of the Soviet Union under Stalin. Events in 1956 propelled Kołakowski onto the public stage, becoming Poland's best-known Marxist. Outspoken, his works were widely published in the Thaw press and in underground editions. His political parable "The Priest and the Jester," published in Twórczośc in 1959, is a case in point. In it he contrasts the attitude of the jester and the priest. The priest lives in blind certainty that his faith is right whereas "the jester's constant effort is to consider all the possible reasons for contradictory ideas. ... In a world where apparently everything has already happened, he represents an active imagination defined by the opposition it must overcome. ${ }^{.52}$ In short, the jester teaches us to "mistrust the stabilized world" or narrow-minded determinism. This was an argumen that, in the Soviet context, raised questions about the relations of intellectuals to power. After all, many-Kołakowski included—had once been loyal and enthusiastic supporters of the communist project. In this sense, the Thaw alliance of Marxism and existentialist humanism did not set out to destroy socialism but to renew it.

\section{BX58}

Planned during these turbulent years, the Polish pavilion for Expo 58 was, perhaps, the most complete and, because it was never realised, an incomplete expression of what might be called "Thaw humanism." The design emerged following a competition managed by the official artists' and architects' unions in the People's Republic in 1956. The winning entry, entitled BX58, was designed by a team led by Jerzy Sołtan, an architect who had returned to Poland in 1949 after working in Le Corbusier's studio in Paris, and Zbigniew Ihnatowicz, archi- 


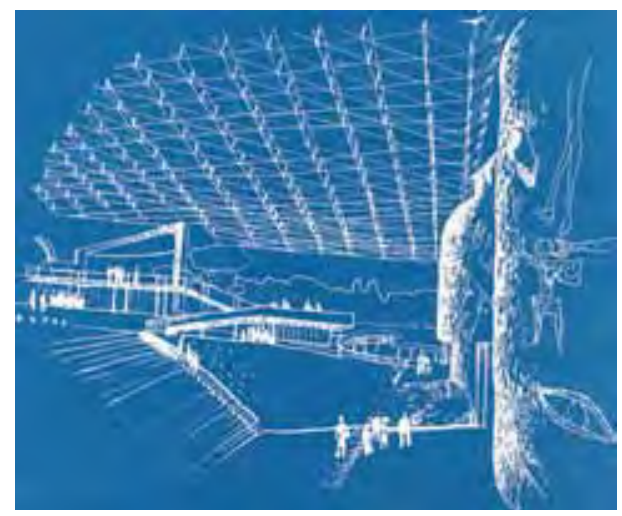

Fig. 6

Jerzy Sottan and others, view of the southern wall and entrance to BX58, the winning design in the competition to design the Polish pavilion at Expo 58, Brussels, 1956. Source: Architektura 8 (August 1957).

tect of some of the most ambitious modernist schemes in Warsaw before the blinkers of socialist realism were imposed on Polish architecture. Other members of this group included the painter Wojciech Fangor; Stanisław Skoraczewski, a pioneer in the development of electronic music in Poland; and designer Lech Tomaszewski.

In the BX58 scheme, the pavilion was to be fragmented into architectural elements that would be seemingly recomposed by the movement of the visitor. Visitors were to ascend elevated "communication platforms" where they would encounter exhibition displays and four curved cinema screens. This was to be a multimedia experience: the viewer was to encounter electro-acoustic sounds composed by Skoraczewski. The imagery on the screens--combining images of everyday life and abstract film--and the sounds would change as visitors passed by as if triggered by the movement of their bodies. It appears that the films were never made for the pavilion, but an early published proposal suggested their content: "on work (for instance on mining safety), on individual life (perhaps on free time), on intellectual life (perhaps on [Ksawery] Dunikowski's sculpture), as well as on body culture (for instance on the Peace [Bicycle] Race). ${ }^{{ }^{53}}$ Skoraczewski's music, composed as a single work, was to unite these different aspects of life into a whole. The design of the pavilion turned, according to Sołtan, interviewed late in his life, to "all means of communication, assaulting simultaneously the largest number of human senses. In this context of total experience, the architectural shell was not to have an autonomous role. ${ }^{54}$ In fact, the visitor was to become the exhibition medium in a sense suggested by Merleau-Ponty when he wrote that the senses "inter-communicate through the medium of my body; a ready-made system of equivalents and transpositions from one sense to another.$^{5}$

The Polish pavilion was conceived as the entire site. Its "parasol" roof, platform, and screens were to be raised on thin piloti, leaving the plants and trees on the site untouched (fig. 6). Here the public could escape the tyranny of the exhibition route. In fact, the building itself was to disappear. The entire site given over to Poland was to be covered under a massive floating roof structure constructed from modular pyramidal forms, each "conceived as a kind of crystal. ${ }^{\prime 6}$ Tomaszewski's innovative and much-lauded roof structure was to emerge from the ground on one side of the triangular site. On another side, it sat on a 
Fig. 7 (top)

Presentation drawing featuring Wojciech Fangor's mural scheme for the winning entry in the competition to design the Polish pavilion at Expo 58, Brussels, 1956. Source: Collection of the Warsaw Academy of Fine Art.

Fig. 8 (bottom) Oskar Hansen, design for a temporary exhibition structure entitled "Moje Miejsce, Moja Muzyka" ("My Place, My Music") at the Annual International Festival of Contemporary Music, Warsaw, 1958. Source:

Collection of the Warsaw Academy of Fine Art. rippling perimeter wall decorated with painted motifs by Fangor. In one scheme, the artist presented a narrative of humanity's progress from primitive violence and slavery to the discovery of the cosmos (fig. 7). Although this teleology was not directly antagonistic to the Soviet conception of history (and the artist made reference to Poland's fraternal neighbor by his employment of the symbol of the hammer and sickle), Fangor's treatment was self-consciously primitive. He presented this narrative in the manner of the cave paintings in Lascaux, in the Dordogne region of France, which were discovered in 1940 and were still, in the postwar years, the focus of considerable intellectual attention. In 1955 Georges Bataille wrote, "the meaning of Lascaux . . . is . . the shift from the world of work to the world of play; of the transition from Homo Faber to Homo Sapiens." 57 Fangor's screen functioned in a similar fashion: it signaled entry into a space for thought, not in the contemplative or transcendental sense but as a precondition of action. The pavilion was to engage the active imagination.

A network of intellectual correspondences and personal connections links the Polish design to many Western experiments, but perhaps the most important intellectual synapse was that formed with the thinking of Oskar Hansen, a close colleague of the Polish team. Hansen was the author of "Otwarta Form" (Open Form), a theory published in $1957 .{ }^{58}$ In this short manifesto, he argued for spatial forms that were incomplete and, by their incompleteness, required the creativity or participation of viewers or users. Space, according to Hansen, should be considered in terms of movement, whether in its synchronic potential to be reorganized by those who occupy it, or in its diachronic capacity to change over time. In engaging their audiences or users, open forms had the potential to remind audiences of the fact of their own embodied being. They would also make the individual more attuned to the ordinary: "As Dadaism in painting broke the barrier of traditional aesthetics, so the Open Form in architecture will also bring us closer to the "ordinary, mundane, things found, broken, accidental." ${ }^{59}$ This was fundamentally a social and decentered conception of space and creativity. Hansen's theory also offered new ways to conceptualize modern architecture. Buildings designed as "open forms" would be positively
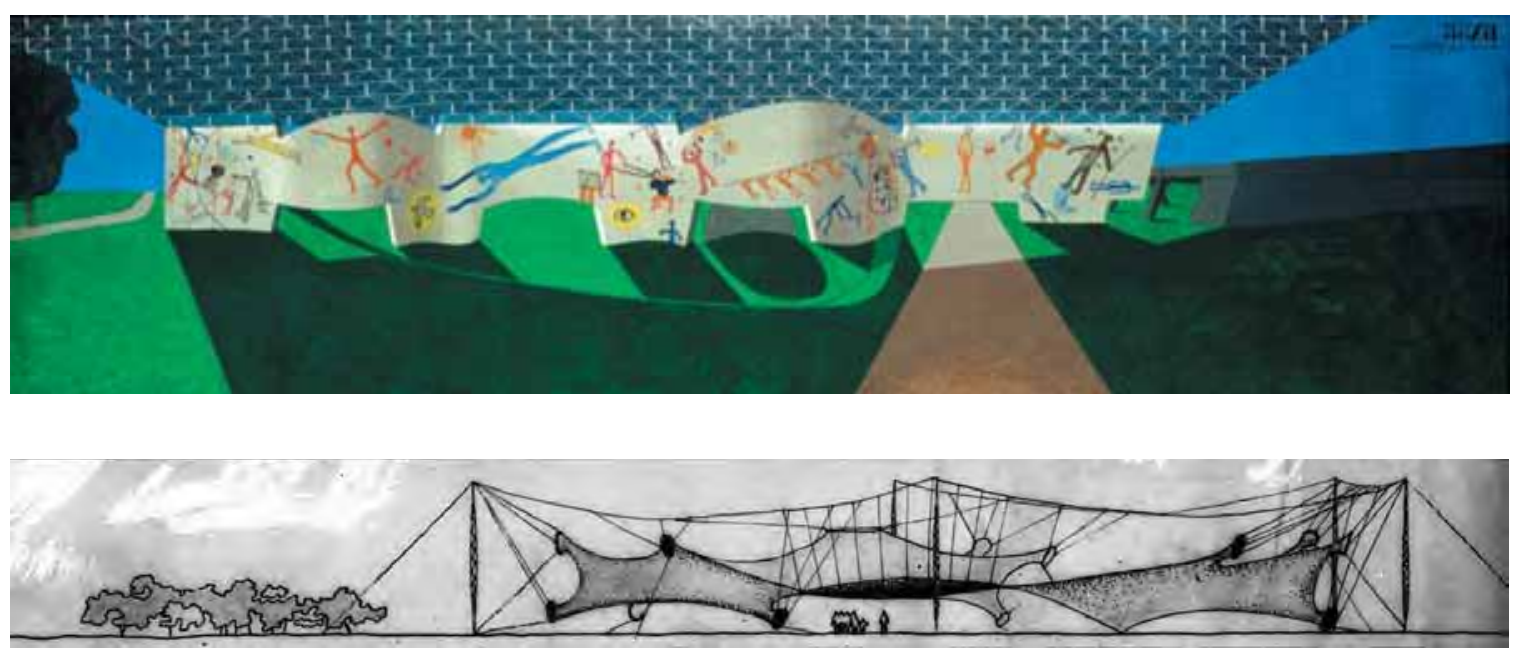
"incomplete," leaving opportunities for occupants to shape their environment in meaningful ways. Because of its promise of universal application, Hansen saw the open form as a way of rethinking public memorials, housing developments, and works of art. ${ }^{60}$

The open form was frequently discussed in terms of exhibition and display, despite the associations of spectacle with distraction, amusement, and alienation. He designed, for instance, the "Moje Miejsce, Moja Muzyka" ("My Place, My Music") pavilion for the Annual International Festival of Contemporary Music in 1958, an important forum for experimental composers. Working with Józef Patkowski, a pioneer of electronic music, Hansen experimented with the "spatiality of music" — what he called an "audiovisual space-time." A large fabric structure was to be suspended in a park, like a shirt with sleeves, each equipped with a speaker at its end (fig. 8). Viewers were to be encouraged to move through the space. In Hansen's words "each could walk their chosen path in relation to the music--almost as if they owned it. . . The spatial relativity of the music's reception brought the listener closer to an intimate experience of it ... integrating sound with the listeners' movements as well as with the trees and clouds." ${ }^{61}$ Hansen's aim was not the stimulation of sensation but of imagination.

Lacking any clear reference to ideology, Hansen's epen form theory might, at first, appear to be apolitical. But it needs to be understood in terms of debates about alienation in Poland in the mid-1950s. It was an intellectual analogue of Kołakowski's conception of the "active imagination," and from this perspective, it can be characterized as a form of utopianism that imagined the whole individual (or what Marx once called "the dream of the whole man"). The BX58 scheme for Brussels can be viewed in similar terms. It was to be an open form in the sense that Sołtan and his colleagues sought to encourage what Theodor Adorno called "the ambiguity in which thought originates." ${ }^{62}$ This was not an eschewal of the imperative to communicate (after all, it employed all available means of communication) but a refusal of the concept of "the message." After Stalin, no message could or should be accepted as a matter of faith.

Despite its powerful intellectual appeal, the scheme faltered. The initial response to the BX58 design, when it was selected for the pavilion, was one of controversy, vented at a lively public debate in the National Theatre in Warsaw and on the pages of the Polish press. One commentator, for instance, attacked the design as being too theatrical and "emotional." ${ }^{63}$ But, most important, the design did not attract the support of the state. In February 1957, the press reported the official view that Poland "could not present ourselves to the world as the megalomaniac builders of gigantic pavilions" (an unfortunate judgment given the architects' eschewal of monumentalism) ${ }^{64}$ Viewed as too expensive, the scheme was shelved after an abortive attempt to produce a smaller version by combining Soltan and Ihnatowicz's scheme with that of another team in the competition led by Hansen. Although never built and, as such, unencumbered with exhibits, slogans, or other projections of the national ego, the BX58 scheme nevertheless remains a lucid statement about the potential of the active imagination in architectural design. 


\section{Effects}

The Czechoslovak dramaturgy in the Laterna Magika performances at Brussels attempted to lever open the image to critical scrutiny through one form of the Verfremdungseffekt; while the Polish pavilion promised the restoration of the subject through the exposure of the senses to different media. In searching for a new image of humanity after the catastrophe of Stalinism, these artists and architects accepted the challenge to produce not "better" images but "better" spectators. Remarkable and highly original, even by international standards set by Le Corbusier or André Wogenscky, these schemes remain difficult to assess by their "own" criteria. The Polish pavilion was never built and so clearly never gathered an audience. But what can we say about the Laterna Magika in this regard?

It seems that Laterna Magika in Brussels struggled to achieve its effects. A frequent response to its daily performances was one of high amusement rather than critical reflection. In fact, Le Soir recommended the spectacle but asked ts readers to "allow for," that is, ignore, its "political considerations." 65 Away from the Czechoslovak context, where its particular Verfremdungseffekt had the power of critique, Laterna Magika simply offered another order of pleasure. In the West, montage-its central technique-was an enervated aesthetic, enfeebled by its use in commercial film and advertising. Writing in the 1960s, Adorno was to ring the death knell on the technique: "The principle of montage was conceived as an act against surreptitiously achieved organic unity: it was meant to shock. Once this shock is neutralised, the assemblage once more becomes merely indifferent material: the technique no longer suffices to trigger communication between the aesthetic and the extra-aesthetic, and its interest dwindles to a cultural-historical curiosity." ${ }^{66}$ In Brussels the Laterna Magika was precisely this, an enchanting alternative to the seamless Circarama show or Charles and Ray Eames's humorous animation for the IBM pavilion, "The Information Age. ${ }^{67}$ In this light, it is not surprising that Svoboda's skills as a $\bar{\equiv}$ ner were much in demand in Czechoslovakia and in the West after his succès d'estime in Brussels. Chief designer of the National Theatre in Prague until the 1970s, he returned to the international stage at Expo 67 in Montreal, when he designed an elaborate Polyekran (multiscreen cinema). He even received an invitation to design a multimedia environment for the United States at the Osaka World's Fair in $1970 .{ }^{68}$ His proposal to stream dozens of films from an orbiting satellite onto screens in the American pavilion stretched even the superpower's capacities. It was not realized.

\section{David Crowley}

David Crowley is professor and head of the Department of Critical Writing in Art and Design at the Royal College of Art in London. 
1 Bruno Zevi, “Bruxelles 1958: primi interrogative," L'architettura, May 1958, 4.

2 This phrase was a reference to the title of Erich Fromm's 1942 book in which he had arscribed the irrational appeal of fascism in psychoanalytical terms.

3 Expo 58, news release no. 2 (undated) (British Library SA 60/28).

4 Kristin Ross, Fast Cars, Clean Bodies: Decolonization and the Reordering of French Culture (Cambridge,

MA, 1996), 158.

5 For discussion of the planning and architecture of Expo 58 see Mil De Kooning and Rika Devos, L'Architecture Moderne à l'Expo 58 (Brussels, 2006) and M. Kint, Expo 58 als belichaming van het humanistisch modernisme (Rotterdam, 2001). For discussion of Belgian displays see Fredie Floré and Mil De Kooning, "The Representation of Modern Domesticity in the Belgian Section of the Brussels World's Fair of 1958," Journal of Design History 16, no. 4 (2003), 319-340.

6 Greg Castillo, "Domesticating the Cold War: Household Consumption as Propaganda in Marshall Plan Germany," Journal of Contemporary History 40, no. 2 (April 2005): 261-288.

7 André Malraux, Essais de psychologie de l'art I: Le Musée imaginaire (Geneva, 1947).

8 Maurice Lambilliotte in Synthèse (Brussels, 1962), 21. The exhibition was accompanied by a book edited by Emile Langui, 50 Ans d'Art Moderne (Brussels, 1958).

9 Howard Fussiner, "Art at the World's Fair," College Art Journal 18, no. 1 (Autumn 1958): 68.

10 Matthew Stanard, “ 'Bilan du monde pour un monde plus déshumanisé’: The 1958 Brussels World's Fair and Belgian Perceptions of the Congo," European History Quarterly 35, no. 2 (2005): 267-298.

11 Sight 1 (1956): 8.

12 Alexandre Persitz, “Notes et Images," Architecture D'Aujourd'hui 81 (December 1958): 94.

13 "Laying claim to and denying the human condition at the same time: the contradiction is explosive. ... We are living at the moment when the match is put to the fuse." Jean-Paul Sartre, preface to Wretched of the Earth, by Frantz Fanon (1961; Harmondsworth, UK, 1967), 17.

14 Bolesław Bierut, Sześcioletni plan odbudowy Warszawy (Warsaw, 1950), 256. In a typical article of the period, for instance, Irena Dworakowska described the new landscape of the socialist city being built under the guidance of Soviet principles: "Socialist parks of culture should not only compensate for social injustice, but they should also be landscapes created by the invention of artists; humanist landscapes in which man plays the main role; landscapes created with the conviction of the existence of knowable and objective facts about the world, as well as the marvelous possibility that the world can be shaped by humanity for the good of mankind" ("O Parku Kultury Na Powiślu," Architektura, no. 2 [1953]: 278).

15 See Congrès Internationaux d'Architecture Moderne, The Heart of the City: Towards the Humanisation of Urban Life (conference proceedings edited by J. Trywhitt, J. L. Sert, and E. N. Rogers) (London, 1952).

16 Barry Curtis, "The Heart of the City," in Non-Plan: Essays on Freedom, Participation and Change in Modern Architecture and Urbanism, ed. Jonathan Hughes and Simon Salder (Oxford, 2000), 52.

17 Ignasi de Solà-Morales, Differences: Topographies of Contemporary Architecture (Cambridge, MA, 1997), 42.

18 Sarah Nilsen, Projecting America, 1958: Film and Cultural Diplomacy at the Brussels Worlds Fair (Jefferson, NC, 2011), 69-80.

19 See Nilsen, Projecting America, 60-79.

20 For discussion of the Soviet pavilion at Brussels see Susan E. Reid, "The Soviet Pavilion at Brussels '58: Convergence, Conversion, Critical Assimilation, or Transculturation?” (working paper 61, Cold War International History Project, Woodrow Wilson International Center for Scholars, Washington, 2010).

21 Jane Fiske McCullogh, “More Impressions of Expo 58," Industrial Design 5, no. 8 (August 1958): 32.

22 Richard P. Lohse, "Expo 58. Bemerkungen zum Problem der Weltausstellungen," Neue Grafik 2

(July 1958): 11.

23 See Marc Treib, Space Calculated in Seconds (Princeton, NJ, 1996).

24 Le Corbusier, Le Poème Electronique (Paris, 1958), 24-25.

25 A. Wogenscky, "Architecture Active," Cimaise 7, nos. 45-46 (1960): 96-106.

26 See Eric J. Sandeen, Picturing an Exhibition: The Family of Man and 1950s America (Albuquerque, 2005). See also Blake Stimson, The Pivot of the World: Photography and Its Nation (Cambridge, 2005). 27 Roland Barthes, "The Great Family of Man," in Mythologies (London, 1973), 101.

28 This perspective developed after Barthes attended the Berliner Ensemble's performance of "Mother Courage and Her Children" at the Paris International Festival in May 1954. See Louis-Jean Calvet, Roland Barthes: A Biography (London, 1994), 111.

29 Bertolt Brecht, "On the Experimental Theatre," The Tulane Drama Review 6, no. 1 (September 1961): 5. Emphasis in original.

30 Roland Barthes, "Brecht, Marx et l'Histoire," in Oeuvres completes, vol. 1 (Paris, 1993), 755.

31 Nikita S. Khrushchev, For Victory in Peaceful Competition with Capitalism (New York, 1960). On the Czechoslovak pavilion and its contents, see a theme issue of Architektura ČSR 17, nos. 9-10 (September-October 1958): 645-684. 
32 Josef Svoboda, The Secret of Theatrical Space (New York, 1993), 104.

33 See various essays in David Crowley and Jane Pavitt, eds., Cold War Modern: Design 1945-1970

(London, 2008) and Greg Castillo, Cold War on the Home Front: The Soft Power of Midcentury Design

(Minneapolis, 2010). For specific discussion of the Czechoslovak pavilion and its contents see essays in Daniela Kramerová and Vanda Skálková, eds., Bruselský Sen: Českoslovesnka učast na světové výstavé Expo 58 v Bruselua životní styl 1. poloviny 60. let (Prague, 2008).

34 Set designer Svoboda was also the author of a "polyekran" (multiscreen) cinema in the Czechoslovak pavilion; see Denis Bablet, Josef Svoboda (Lausanne, 1970), 127-129.

35 Jirí Cieslar, "Living with the Long Journey: Alfréd Radok's Daleká Cesta," in Holocaust and the Moving Image: Representations in Film and Television Since 1933, ed. Toby Haggith and Joanna Newman (New York, 2005), 217-223.

36 See various essays in Eva Stehlíková, ed., Alfréd Radok mezi divadlem a filmem (Prague, 2007).

37 Interview with Alfréd Radok in Antonín J. Liehm, Closely Watched Films (New York, 1974), 50.

38 Svoboda, Secret of Theatrical Space, 110.

39 Jan Grossman "Výtvarné hledisko Laterny magiky a polyekranu," Výtvarné uměni Art 11 (November 1961): 208.

40 Francis Boite, "La Lanterne Magique” La Nouvelle Gazette, 21 May 1958.

41 Interview with Alfréd Radok in Liehm, Closely Watched Films, 43.

42 For a discussion of Radok's conception of the image, see Jarka Burian, "Alfred Radok's

Contribution to Post-War Czech Theatre," Theatre Survey 22 (1981): 213-228.

43 See Jan Grossman, "Sila ve nosti," Divadlo 10 (October 1961): 586.

44 Bablet, Josef Svoboda, 115.

45 Gilles Deleuze, Difference and Repetition (1969; London, 1997), 37.

46 See Richard T. de George, "The Soviet Concept of Man," Studies in East European Thought 4, no. 4 (December 1964): 261-276.

47 See Mark Poster, Existential Marxism in Postwar France (Princeton, NJ, 1975), 120-123.

48 Jean Paul Sartre, Existentialism and Humanism (1948; London, 1973), 55-56.

49 Hansjakob Stehle, Independent Satellite (London, 1965), 199.

50 Andrzej Friszke, Opozycja polityczna w PRL, 1945-1980 (London, 1994), 67-77.

51 Paweł Machcewicz, "Intellectuals and Mass Movements, Ideologies and Political Programs in Poland in 1956," in Intellectual Life and the First Crisis of State Socialism in East Central Europe, 1953-1956, ed. György Péteri (Trondheim, 2001), 127.

52 Leszek Kołakowski, “The Priest and the Jester," Twórczošč, 1959, reproduced in Leszek Kołakowski, Toward a Marxist Humanism: Essays on the Left Today (New York, 1968), 34.

53 It is difficult to speculate on the content of the proposed films. One of the BX58 team, Karol Małcuyński, was the author of the script of one of the most provocative films made in Poland in the period, Uwaga Chuligany (1955). This film belongs to the genre of gritty social documentaries known as the "Black series," which were made between 1955 and 1957 in Poland. In the words of one of their makers, Kazimierz Karabasz, they sought to "show on screen a reality filled with crudity, falsehood, sadness--themes that thus far had been carefully avoided."

54 Jerzy Sołtan, "Kochany Biszo," in Jerzy Sottan, ed. Jola Gola, ed., (Warsaw, 1995), 320. See also Jerzy Sołtan, "Projekt pawilion wystwawego w Brukseli," Architektura 8 (August 1957): 285.

55 Maurice Merleau-Ponty, Phenomenology of Perception (London, 1979), 234-235.

56 See Lech Tomaszewski, exhibition catalogue published by Warsaw Academy of Art (Warsaw, 1988).

57 Georges Bataille, Prehistoric Painting: Lascaux or the Birth of Art (Lausanne, 1955), 27

58 Oskar Hansen, “Otwarta Form," Przeglad Kulturalny no. 5 (1957): 5.

59 Oskar Hansen in Oscar Newman, CIAM '59 in Otterlo, Documents of Modern Architecture

(Hilversum, Netherlands, 1961), 191.

60 Katarzyna Murawska-Muthesius, "Oskar Hansen, Henry Moore and the Auschwitz Memorial debates in Poland, 1958-59," in Figuration/Abstraction: Strategies for Public Sculpture in Europe 1945-1968, ed. Charlotte Benton (London, 2004), 193-211.

61 Oskar Hansen, Towards Open Form (Frankfurt, 2005), 136.

62 Theodor Adorno, Aesthetic Theory (1970; London, 2004), 316.

63 AC, "Konkurs na Polski Pawillon w Brukseli. Wrażenia z wystawy," Stolica 25 (1956): 2-3.

64 Anon., "Bruksela 1958," Projekt, February 1957, 37.

65 Le Soir cited in Tchecoslovaquie Brussels 58, 2 June 1958, 48.

66 Adorno, Aesthetic Theory, 204.

67 Ben Highmore, "Machinic Magic: IBM at the 1964-1965 New York World's Fair," New Formations 51 (2003): 128-148.

68 Svoboda, Secret of Theatrical Space, 106. 